\title{
The Influence of Electronic Word-of-Mouth, Destination Image, Destination Familiarity and Attitude Toward Destination on Travel Intention to Lombok
}

\author{
I Gusti Ngurah Ary Wiwekananda ${ }^{1}$, Daniel Tumpal H. Aruan² \\ \{wiwekanandaary@gmail.com ${ }^{1}$, dtumpal.ui.ac.id ${ }^{2}$ \}
}

\begin{abstract}
Magister of Management, Faculty of Economy and Business, University of Indonesia, Jakarta ${ }^{1}$, Management Department, Faculty of Economy and Business, University of Indonesia, Jakarta ${ }^{2}$
\end{abstract}

\begin{abstract}
This study aims to determine and analyze the influence of electronic word of mouth, destination image, destination familiarity, and attitude towards destination in the tourism sector. In this case the researchers provide several limitations of research related to the object to be studied, namely online review with the destination of Lombok. Data obtained by distributing questionnaires to the sample as respondents who have criteria; have read online travel reviews for Lombok destinations and have never been to Lombok. The sampling technique used is non-probability sampling with a purposive sampling approach. Samples collected were 163 respondents. Data analysis using Partial Least Square (PLS) and assisted by SmartPLS 3.0 software. The hypotheses formed for testing are: (1) e-wom influences travel intention, destination image, and attitude toward destination positively; (2) destination familiarity influences destination image and travel intention positively; (3) destination image influences attitude toward destination and travel intention, and (4) attitude toward destination influences travel intention positively. Based on the results of processing the statistical data it was found that all hypotheses were accepted.
\end{abstract}

Keywords: Electronic word-of-mouth, Destination image, Destination familiarity, Attitude toward destination, Travel intention, Lombok.

\section{Introduction}

Tourism is one sector that can affect the growth and development of a country. Indonesia as a tropical country has beautiful natural scenery and diverse cultures so that it will strongly support the development of the tourism sector because it attracts tourists to visit. One of the sectors that can collect the most foreign exchange in Indonesia is through the tourism sector. In 2009 the total foreign exchange income from the tourism sector amounted to USD 6.3 billion until 2019, estimated to increase to USD 17.6 billion [1]. In 2018, Indonesia was visited by foreign tourists with a total of 136.2 million visits, an increase from the previous year of $8.34 \%$. Tourism is one of the sectors that is most considered by the Indonesian government at this time. In 2017 the Ministry of Tourism developed a tourism marketing strategy by setting "10 Destinasi Prioritas" with the goal of being able to match or exceed the achievements of Bali as a tourism destination. Lombok as one of the super priority destinations that gets more attention from the government because it has many attractions that can attract tourists such as destinations, beaches, mountains, and cultural diversity. In fact, Lombok cannot reach the targeted number of tourists as many as 4 million tourists from the 
division of 2 million local tourists and 2 million foreign tourists. According to [2] one of the factors that can attract tourists to visit a destination is to use electronic word-of-mouth. The intended electronic word-of-mouth can be user generated content on social media or online travel review platforms such as TripAdvisor, Lonely Planet, Couch Surfing etc. Information owned by someone through electronic word-of-mouth can create an image of a destination and a person's attitude towards a destination [3]. There are other factors that can affect the image and interest of someone to visit the destination familiarity [4]. So that this study will prove the effect of each variable, namely electronic word-of-mouth, destination image, attitude toward destination, and destination familiarity to travel intention.

\section{Literature Review}

\subsection{Electronic Word-of-Mouth}

An activity of disseminating information between individuals carried out noncommercially related to an object is called word-of-mouth [5]. Technological developments produce electronic word-of-mouth where a person can obtain information online [6]. Meanwhile, according to [7] social media including websites and online platforms is a media for someone to share their experiences in new ways. Litvin et al [8] argues that electronic word-of-mouth is the delivery of positive or negative information conveyed by someone through the internet media. Lee \& Koo [9] argues that someone will see information provided by consumers who already have experience. Previous research [3], [10] found that electronic word-of-mouth is one factor for someone in determining the destination.

(H1) Electronic Word-of-Mouth has a positive effect on Travel Intention

(H2) Electronic Word-of-Mouth has a positive effect on Destination Image

(H3) Electronic Word-of-Mouth has a positive effect on Attitude Toward Destination

\subsection{Destination Image}

Destination image is a topic that is often used in research on tourism, and has a diverse understanding based on research that has been done before. Crompton [11] defining destination image is a group of ideas, beliefs, and impressions of an area of destination that exists in a person. Lopes [12] explains that destination image is an expression of all objective knowledge, prejudice, imagination and emotional thoughts of a person towards an area or destination. Destination image is a perception that arises because of the various information received by a person or tourist [13]. Destination image that is owned by someone is the main consideration of one's interest in making a visit or tour [14].

(H5) Destination Image has positive effect on Attitude Toward Destination

(H7) Destination Image has positive effect on Travel Intention

\subsection{Tourist Attitude Toward Destination}

The attitude of tourists describes psychological tendencies expressed both by positive and negative evaluations. Attitude is an overall evaluation by someone in their behavior [15]. Attitude can also be interpreted as a tendency that arises due to the results of one's learning and experience, so in the context of tourism attitude can be interpreted as a tendency or feeling of a tourist towards the services, entertainment or attractions owned by a tourist destination [16]. In the context of tourism, thought is related to one's attitude in visiting a tourist 
destination that can be evaluated from several things such as whether the tourist destination is attractive or unattractive, fun or boring, positive or negative [17].

(H8) Attitude Toward Destination has a positive effect on Travel Intention

\subsection{Destination Familiarity}

The concept of familiarity is often combined with other related concepts such as awareness, knowledge, experience, and expertise [18]. Familiarity is considered a subjective knowledge in addition to objective knowledge and prior knowledge, subjective knowledge shows how much individuals think they know and often that will reflect the person's selfconfidence [19]. Destination familiarity is how someone's visual or mental impression of a destination or tourist experience and can stimulate someone's interest to travel and visit the destination [20]. Perception of service quality, personality, or satisfaction can affect the evaluation process of destination familiarity, thus determining a person's attitude and interest in traveling to the destination [21]. Horng et al [22] in his research found the results of destination familiarity can be a moderating variable between brand image and travel intention.

(H4) Destination Familiarity has positive effect on Destination Image

(H6) Destination Familiarity has positive effect on Travel Intention

\subsection{Travel Intention}

According to [23] explain intention is something that we want or plan to do, whereas [24] interpret intentions as an indication of the readiness of a tourist to perform certain behaviors, and is considered as a direct antecedent of a behavior. In the context of tourism Chu \& Luckanavanich [23] said that someone's interest to visit a destination is very important and fundamental when someone decides to visit a destination. Jalilvand et al [3] in his research said that the interest in visiting is influenced by several aspects or variables such as destination image, attitude towards destination, and electronic word-of-mouth, Tan \& Wu [25] added that the familiarity (familiarity) of a person can also affect one's interest in visiting a tourist destination.

\section{Method}

In previous studies [3], testing the effect of electronic word-of-mouth, destination image, attitude toward destination on travel intention. Other research [4], [22], [26] add destination familiarity variables as moderation between destination image and travel intention. While [25] found that destination familiarity can directly influence destination image and travel intention. 


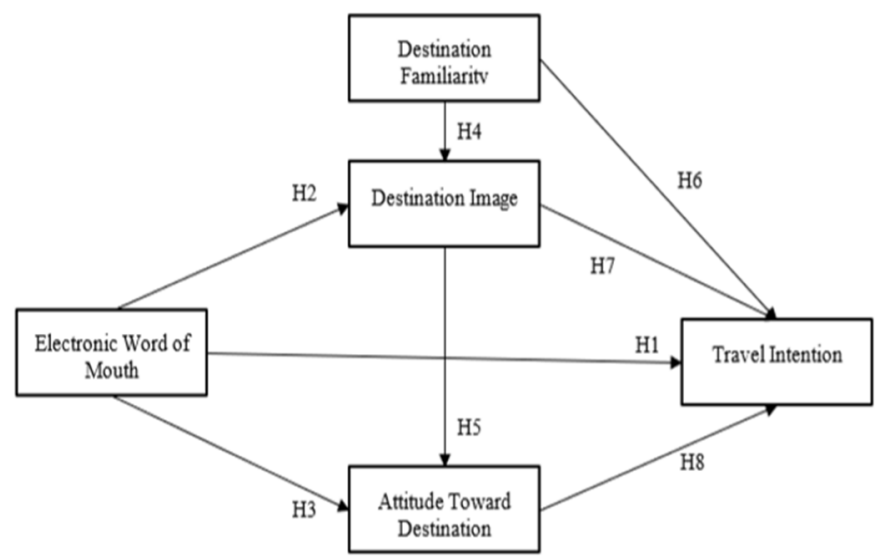

Fig.1. A Conceptual Research Model

This research includes quantitative descriptive research. Descriptive research design is used to describe electronic word-of-mouth towards travel intention and describe the views of prospective tourists on the attitude toward destination and destination image of Lombok Island that is accessed online. Data were collected using a questionnaire and carried out online using Qualtrics. The population in this study are people who have never been to Lombok and have seen online reviews of Lombok destinations. Determination of the sample in this study is Nonprobability Sampling with purposive sampling technique so that the number of samples found as many as 163 respondents.

\section{Result And Discussion}

The researcher conducts wording and pre-test before entering core research. The recording test was conducted by involving 5 people to find out the appropriateness of the statements on the questionnaire. Pre-test was conducted involving 30 respondents to determine the validity and reliability of the model used with SPSS 25 application. Based on the pre-test results it is known that Destination Image, Attitude Toward Destination, Destination Familiarity and Travel Intention are said to be valid (Kaiser-Meyer-Olkin $>0.5$ and Component Matrix $>0.5$, while Electronic Word-of-Mouth has one indicator having a component matrix value $<0.5$ so that the indicator cannot be used in core research, reliability testing shows that all variables are reliable (Cronbach's Alpha $>0.6$ ). After conducting the pre-test, the researcher conducted a core study using all samples with statistical processing using Smart PLS 3. Data analysis using this software was carried out through three stages, namely the outer test, the inner test and the hypothesis test (Hair et al. 2014). The first stage conducted is the outer test to determine the validity and reliability of each variable, the validity test is used to determine whether a model or instrument used is appropriate and feasible to be measured [28]. Validity can be measured in two ways, first by looking at convergent validity (loading factor $>0.7$ ) is a test conducted to determine the relationship with the belief that a construct must have a sufficient correlation value [29], and second by discriminant validity is a test to find out which variables are said to be valid on the basis that each construct of the model has a high correlation value. Reliability relates to whether the results shown have the same or consistent values if research is carried 
out with different times or objects (Average Variance Extracted $>0.5$, Composite Reliability $>$ 0.7, and Cronbach Alpha > 0.6) [28].

\subsection{Outer Model Testing}

In this research, it is known that all variables are declared valid (Electronic Word-ofMouth has a loading factor value between 0.711 to 0.845 , Destination Image has a loading factor value between 0.809 to 0.827 , attitude toward destination has a loading factor value of 0.878 to 0.908 , destination familiarity has loading factor value 0.831 to 0.923 , and travel intention has a loading factor value 0.826 to 0.863 ) and discriminant validity of each variable has a higher cross loading value than other variables. This study has a reliable variable, electronic word-of-mouth variable has a composite reliability value of 0.926 , and cronbach alpha is 0.880 , destination image has a composite reliability value of 0.951 and cronbach alpha is 0.939 , attitude toward destination has a composite reliability value of 0.891 and cronbach alpha which is 0.837 , destination familiarity has a composite reliability value of 0.892 and cronbach alpha which is 0.848 , and travel intention has a composite reliability value of 0.884 and cronbach alpha which is 0.805 .

\subsection{Inner Model Testing}

Afterwards, the inner model test phase was found that the coefficient of determination $\left(\mathrm{R}^{2}\right)$ on attitudes toward the destination was 0.537 , the destination image was 0.375 , and the travel intention was 0.561 . The researcher also calculates the level of accuracy of the $\mathrm{R}^{2}$ value which has a value between 0 to 1 , the higher the $\mathrm{R}^{2}$ value means the higher the level of accuracy possessed. Based on the results of the outer and inner test models that have been done before, the model meets the requirements for hypothesis testing. The results of the calculation of goodness of fit can be used to determine the amount of contribution exogenous variables have given to endogenous variables. In the PLS analysis the results of goodness of fit are obtained through q-square $\left(\mathrm{Q}^{2}\right)$. Calculation results that exceed 0 are considered to have a good predictive value. How good the predicted value generated by the model and the estimated parameters in this study will be shown from the following Q2 calculation:

$$
\begin{aligned}
& \mathrm{Q}^{2}=1-\left[\left(1-\mathrm{R} 1^{2}\right) \times\left(1-\mathrm{R} 2^{2}\right) \times\left(1-\mathrm{R} 3^{2}\right)\right] \\
& \mathrm{Q}^{2}=1-[(1-0,537) \times(1-0,375) \times(1-0,561)] \\
& \mathrm{Q}^{2}=1-(0,463 \times 0,625 \times 0,439) \\
& \mathrm{Q}^{2}=1-0,127=0,873
\end{aligned}
$$

Notes: $\mathrm{Q}^{2}=$ Predictive Relevance value, $\mathrm{R} 1^{2}=\mathrm{R}$-Square value for Attitude Toward Destination variable, $\mathrm{R} 2^{2}=\mathrm{R}$ Square value for Destination Image variable, $\mathrm{R} 3^{2}=\mathrm{R}$-Square value for Travel Intention variable.

The calculation result is 0.873 or $87.3 \%$, so it can be interpreted that the diversity of data that can be explained in this research model is $87.3 \%$ and the remaining $12.7 \%$ is explained by other variables outside of this research model.

\subsection{Hypothesis Testing}

Implementation of direct influence testing is used to test the hypothesis in this study. This test uses the value of the $\beta$ Values, taking into account the magnitude of the t-statistic value has a value greater than $t$ table $(1.96)$ and the $p$-value $<0.05$ so that it can be concluded that the hypothesis can be accepted, namely there is a positive and significant effect between variables tested. 
Table 1. The results of hypothesis testing

\begin{tabular}{|c|c|c|c|c|}
\hline & Hypothesis & $\beta$ Values & $\begin{array}{l}\text { T- } \\
\text { Statistics }\end{array}$ & P-value \\
\hline H1 & EWOM $\rightarrow$ IT & 0.237 & 3,969 & 0,000 \\
\hline $\mathrm{H} 2$ & EWOM $\rightarrow$ DI & 0.249 & 4,358 & 0,000 \\
\hline H3 & EWOM $\rightarrow$ ATD & 0.175 & 2,638 & 0.009 \\
\hline $\mathrm{H} 4$ & $\mathrm{DF} \rightarrow \mathrm{DI}$ & 0.501 & 8,897 & 0,000 \\
\hline H5 & $\mathrm{DI} \rightarrow \mathrm{ATD}$ & 0.650 & 11,320 & 0,000 \\
\hline H6 & $\mathrm{DF} \rightarrow \mathrm{IT}$ & 0.222 & 2,944 & 0.003 \\
\hline $\mathrm{H} 7$ & $\mathrm{DI} \rightarrow \mathrm{IT}$ & 0.259 & 2,924 & 0.004 \\
\hline $\mathrm{H} 8$ & $\mathrm{ATD} \rightarrow \mathrm{IT}$ & 0.256 & 3,760 & 0,000 \\
\hline
\end{tabular}

From the results, all of the hypotheses were supported by the data. The results showed that Destination Image had the highest positive effect on travel intention ( $\beta$ Values $=0.259$, TStatistic $=2.924$, P-Value $=0.004)$. Based on the results of research in accordance with research conducted by [3] that electronic word-of-mouth has a positive effect on travel intention, destination image, and attitude toward destination. The results of a positive relationship on the destination familiarity variable have a positive effect on destination image and travel intention in line with research [25].

\section{Conclusions}

Based on the results of data processing and discussion, it is known that electronic word-ofmouth, destination image, destination familiarity, and attitude toward destination can be the influence or consideration of someone to visit the Lombok destination. Information shared online affect one's attitude towards the Lombok destination, it is proven that in this study respondents felt Lombok is a very good destination to visit, it is in line with previous research that electronic word-of-mouth has an influence on travel intention [10], Electronic word-ofmouth can also affect directly on the destination image [2]. In addition, tourists feel familiar with Lombok destinations, so they feel comfortable when traveling in Lombok, research conducted by [25] found the same thing that someone can have an interest in visiting a destination because they feel familiar with the destination and can form a good image for tourists.

Thus, based on the results of this study the managerial implications that become a reference for all stakeholders, especially in the tourism sector in increasing one's intention to visit Lombok, are as follows:

a) Use buzz marketing or viral marketing strategies. According to [30] viral marketing is done by creating electronic content such as videos or mini-sites with the aim of building a brand or in this context, destination. So that every activity or event related to tourism in Lombok can be spread online so that it can be seen by many people and become viral.

b) Collaborate with key opinion leaders in delivering information related to tourist destinations in Lombok. Yoo et al [31] proved that the travel opinion leader influences someone in finding information related to the destination and creating an interest in visiting the destination. 
Social media is one of the most effective media to be used as promotional media specifically in the tourism sector [32]. Based on respondents' answers that tourists are more interested in natural attractions in a destination so that the content delivered is more to natural tourist destinations in Lombok such as beaches, mountains, and others

\section{References}

[1] Kementerian Pariwisata dan Kebudayaan, "Berapa Pendapatan Devisa dari Sektor Pariwisata Indonesia? | Databoks,” 2018. [Online]. Available:

https://databoks.katadata.co.id/datapublish/2018/09/10/berapa-pendapatan-devisa-dari-sektorpariwisata-indonesia. [Accessed: 02-Jul-2020].

[2] R. R. Prayogo, F. L. S. Ketaren, and R. M. Hati, "Electronic Word of Mouth, Destination Image, and Satisfaction Toward Visit Intention: an Empirical Study in Malioboro Street, Yogyakarta," no. January, 2017, doi: 10.2991/icosop-16.2017.31.

[3] R. M. Jalilvand, N. Samiei, B. Dini, and P. Yaghoubi Manzari, "Examining the structural relationships of electronic word of mouth, destination image, tourist attitude toward destination and travel intention: An integrated approach," J. Destin. Mark. Manag., vol. 1, no. 1-2, pp. 134-143, 2012, doi: 10.1016/j.jdmm.2012.10.001.

[4] H. K. Chi, K. C. Huang, and H. M. Nguyen, "Elements of destination brand equity and destination familiarity regarding travel intention," J. Retail. Consum. Serv., vol. 52, no. February 2019, p. 101728, 2020, doi: 10.1016/j.jretconser.2018.12.012.

[5] R. Rita, K. Hutomo, and N. Natalia, "Electronic Word of Mouth (e-WOM) Foursquare: The New Social Media," Binus Bus. Rev., vol. 4, no. 2, p. 711, Nov. 2013, doi: 10.21512/bbr.v4i2.1385.

[6] L. C. Lu, W. P. Chang, and H. H. Chang, "Consumer attitudes toward blogger's sponsored recommendations and purchase intention: The effect of sponsorship type, product type, and brand awareness," Comput. Human Behav., vol. 34, pp. 258-266, 2014, doi: 10.1016/j.chb.2014.02.007.

[7] Z. Xiang and U. Gretzel, "Role of social media in online travel information search," Tour. Manag., vol. 31, no. 2, pp. 179-188, Apr. 2010, doi: 10.1016/j.tourman.2009.02.016.

[8] S. W. Litvin, R. E. Goldsmith, and B. Pan, "Electronic word-of-mouth in hospitality and tourism management," Tour. Manag., vol. 29, no. 3, pp. 458-468, 2008, doi: 10.1016/j.tourman.2007.05.011.

[9] K. T. Lee and D. M. Koo, "Effects of attribute and valence of e-WOM on message adoption: Moderating roles of subjective knowledge and regulatory focus," Comput. Human Behav., vol. 28, no. 5, pp. 1974-1984, 2012, doi: 10.1016/j.chb.2012.05.018.

[10] A. M. Abubakar and M. Ilkan, "Impact of online WOM on destination trust and intention to travel: A medical tourism perspective," J. Destin. Mark. Manag., vol. 5, no. 3, pp. 192-201, 2016, doi: 10.1016/j.jdmm.2015.12.005.

[11] J. L. Crompton, "Motivations for pleasure vacation," Ann. Tour. Res., vol. 6, no. 4, pp. 408424, Oct. 1979, doi: 10.1016/0160-7383(79)90004-5.

[12] S. D. Lopes, "Destination image: Origins, Developments and Implications," PASOS Rev. Tur. y Patrim. Cult., vol. 9, no. 2, pp. 305-315, 2011, doi: 10.25145/j.pasos.2011.09.027.

[13] F. Destari, "Meningkatkan Intention To Revisit Melalui Keunikan Jasa Pariwisata \& Destination Image," J. Manaj. dan Kearifan Lokal Indones., vol. 1, no. 1, p. 44, 2017, doi: 10.26805/jmkli.v1i1.4.

[14] P. I. Phau, D. T. Shanka, and N. Dhayan, "Destination Image and Choice Intention of University Student Travellers to Mauritius," Int. J. Contemp. Hosp. Manag., vol. 22, no. 5, 2010, doi: 10.1108/95961190980000623.

[15] S. J. Kraus, "Attitudes and the Prediction of Behavior: A Meta-Analysis of the Empirical Literature," Personal. Soc. Psychol. Bull., vol. 21, no. 1, pp. 58-75, 1995, doi: 
$10.1177 / 0146167295211007$

[16] S. Bresciani, A. Thrassou, and D. Vrontis, "Determinants of performance in the hotel industry An empirical analysis of Italy," in Global Business and Economics Review, 2015, vol. 17, no. 1, pp. 19-34, doi: 10.1504/GBER.2015.066531.

[17] T. Lam and C. H. C. Hsu, "Predicting behavioral intention of choosing a travel destination," Tour. Manag., vol. 27, no. 4, pp. 589-599, Aug. 2006, doi: 10.1016/j.tourman.2005.02.003.

[18] M. Sharifpour, G. Walters, B. W. Ritchie, and C. Winter, "Investigating the Role of Prior Knowledge in Tourist Decision Making: A Structural Equation Model of Risk Perceptions and Information Search," J. Travel Res., vol. 53, no. 3, pp. 307-322, 2014, doi: $10.1177 / 0047287513500390$.

[19] M. Brucks, "The Effects of Product Class Knowledge on Information Search Behavior," J. Consum. Res., vol. 12, no. 1, p. 1, 1985, doi: 10.1086/209031.

[20] A. Milman and A. Pizam, "The Role of Awareness and Familiarity with a," J. Travel reserch, vol. 33 (3), pp. 21-27, 1995, doi: 10.1177/004728759503300304.

[21] R. M. Hernández Maestro, P. A. Muñoz Gallego, and L. Santos Requejo, "The moderating role of familiarity in rural tourism in Spain,” Tour. Manag., vol. 28, no. 4, pp. 951-964, Aug. 2007, doi: 10.1016/j.tourman.2006.08.009.

[22] J. S. Horng, C. H. Liu, H. Y. Chou, and C. Y. Tsai, "Understanding the impact of culinary brand equity and destination familiarity on travel intentions," Tour. Manag., vol. 33, no. 4, pp. 815824, 2012, doi: 10.1016/j.tourman.2011.09.004.

[23] C. Chu and S. Luckanavanich, "The Influence of Social Media Use and Travel Motivation on The Perceived Destination Image and Travel Intention to Taiwan of The Thai People," Int. J. Arts Commer., vol. 7, no. 3, pp. 22-36, 2018.

[24] S. Shen, A. Schüttemeyer, and B. Braun, "Visitors' intention to visit world cultural heritage sites: An empirical study of Suzhou, China," J. Travel Tour. Mark., vol. 26, no. 7, pp. 722-734, Nov. 2009, doi: 10.1080/10548400903284610.

[25] W. K. Tan and C. E. Wu, "An investigation of the relationships among destination familiarity, destination image and future visit intention," J. Destin. Mark. Manag., vol. 5, no. 3, pp. 214226, 2016, doi: 10.1016/j.jdmm.2015.12.008.

[26] S. B. Kim and K. J. Kwon, "Examining the relationships of image and attitude on visit intention to Korea among Tanzanian college students: The moderating effect of familiarity," Sustain., vol. 10, no. 2, 2018, doi: 10.3390/su10020360.

[27] J. F. Hair Jr, L. M. Matthews, R. L. Matthews, and M. Sarstedt, A Primer on Partial Least Squares Structural Equation Modeling (PLS-SEM). 2014.

[28] A. A. P. Agung, "Metodologi Penelitian Bisnis," Malang: Universitas Brawijaya Press (UB Press), 2012.

[29] W. (2009). K. dan aplikasi P. (Partial L. S. untuk penelitian empiris. B. F. E. dan B. U. Y. Jogiyanto, H. M., \& Abdillah, "Konsep dan aplikasi PLS (Partial Least Square) untuk penelitian empiris," BPFE Fak. Ekon. dan Bisnis UGM, 2009.

[30] J. Y. C. Ho and M. Dempsey, "Viral marketing: Motivations to forward online content," J. Bus. Res., vol. 63, no. 9-10, pp. 1000-1006, Sep. 2010, doi: 10.1016/j.jbusres.2008.08.010.

[31] K.-H. Yoo, U. Gretzel, and F. Zach, "Travel Opinion Leaders and Seekers," in Information and Communication Technologies in Tourism 2011, Vienna: Springer Vienna, 2011, pp. 525-535.

[32] B. Zeng and R. Gerritsen, "What do we know about social media in tourism? A review," Tourism Management Perspectives, vol. 10. pp. 27-36, Apr-2014, doi: 10.1016/j.tmp.2014.01.001. 